\title{
A study of large earthquake sequences in the Sumatra subduction zone and its possible implications
}

\author{
Haekal A. Haridhi ${ }^{1,2,3,6}$, Bor-Shouh Huang ${ }^{2, *}$, Kuo-Liang Wen ${ }^{3}$, Deni Denzema ${ }^{4}$, R. Agung Prasetyo ${ }^{4}$, \\ and Chao-Shing Lee ${ }^{5}$ \\ ${ }^{1}$ Taiwan International Graduate Program (TIGP) - Earth System Sciences Program, Academia Sinica and National Central \\ University, Taiwan \\ ${ }^{2}$ Institute of Earth Sciences, Academia Sinica, Taipei City, Taiwan \\ ${ }^{3}$ Department of Earth Sciences, National Central University, Taoyuan City, Taiwan \\ ${ }^{4}$ Badan Meteorologi, Klimatologi, dan Geofisika (BMKG), Jakarta, Indonesia \\ ${ }^{5}$ Institute of Geosciences, National Taiwan Ocean University, Keelung, Taiwan \\ ${ }^{6}$ Department of Marine Sciences, Faculty of Marine and Fisheries, Syiah Kuala University, Banda Aceh, Indonesia
}

\section{Article history:}

Received 26 February 2018

Revised 21 August 2018

Accepted 22 August 2018

Keywords:

Sumatra, Subduction zone, Seismicity, Fracture zone, Splay fault,

Tsunami

Citation:

Haridhi, H. A., B.-S. Huang, K.-L. Wen, D. Denzema, R. A. Prasetyo, and C.-S. Lee, 2018: A study of large earthquake sequences in the Sumatra subduction zone and its possible implications. Terr. Atmos. Ocean. Sci.,29, 635-652, doi: 10.3319/ TAO.2018.08.22.01

\begin{abstract}
Large subduction earthquakes have repeatedly occurred along the Sumatra subduction zone, where the Australian oceanic plate is subducting beneath the Sunda continental plate. We have analyzed two years (2009 to 2011) earthquake data from a regional seismic network along the Sumatra region that provided by the Badan Meteorologi, Klimatologi, dan Geofisika (BMKG) of Indonesia. Based on those data, a regional one-dimensional velocity model was refined first. Then, all events have been relocated based on the hypocenter double difference technique. Based on the relocated earthquake catalogue, three large earthquake sequences with magnitude greater than $\mathrm{Mw} 7.5$ were well identified with one of them induced significant tsunami, thus, the 30 September $2009 \mathrm{Mw} 7.6$ Padang earthquake, the 7 April $2010 \mathrm{Mw}$ 7.8 Banyak Islands earthquake, and the 25 October $2010 \mathrm{Mw} 7.8$ Mentawai tsunami earthquake. The characteristics of these earthquake sequences were analyzed and its possible implications were discussed in this study. A statistical analysis of polynomial linear fitting has been proposed to identify lineation of earthquake pattern in this study. Results indicated that a northwest-southeast dipping of earthquake lineation was identified within the Banyak Islands earthquake sequence and considered as the activity of the upper splay fault. Limited earthquake activity was identified at the Mentawai gap region and considered as a locked asperity. Those faults could be as a major threat of a great source of tsunamigenic fault. This region is considered as a high potential candidate to generate destructive earthquake and tsunami on the Sumatra subduction zone in future.
\end{abstract}

\section{INTRODUCTION}

Sumatra Island is situated at the convergence plate boundary between the oceanic Australian plate and the continent Sunda plate (Fig. 1). Large subduction earthquake and resulting tsunami has repeatedly occurred at this region (Newcomb and McCann 1987; Meltzner et al. 2006; Natawidjaja et al. 2006), such as the giant earthquake and tsunami of 26 December 2004, which is known as the worst natural disaster ever recorded in modern time (Lay et al. 2005).

\footnotetext{
* Corresponding author

E-mail:hwbs@earth.sinica.edu.tw
}

Ever since that disaster, activity of strain accumulates and release is shown increasing (Waldhauser et al. 2012). From 2009 to 2011, the Sumatra subduction zone had experience three large earthquakes with magnitude greater than $\mathrm{Mw}$ 7.5 and one of them has induced significant tsunami, i.e., the 30 September $2009 \mathrm{Mw}$ 7.6 Padang earthquake, the 7 April $2010 \mathrm{Mw} 7.8$ Banyak Islands earthquake, and the 25 October $2010 \mathrm{Mw} 7.8$ Mentawai tsunami earthquake (McCloskey et al. 2010; Bilek et al. 2011; Tsang et al. 2015). Most of the seismicity studies conducted at this region were using observations from local temporary seismic stations 
(Araki et al. 2006; Sibuet et al. 2007; Lin et al. 2009; Lange et al. 2010; Collings et al. 2012) and/or teleseismic stations (Engdahl et al. 2007; McCloskey et al. 2010; Waldhauser et al. 2012). Usually, the local temporary seismic network could give a high resolution of seismic activity, however its recording period is limited, while the teleseismic station could only record the earthquake with larger magnitude. Consequently, the Badan Meteorologi, Klimatologi, dan Geofisika (BMKG) operated a permanent regional seismic network which uniformly covered the entire study region and the recorded data with a larger range of magnitude. The BMKG seismic network is the Indonesia nationwide seismic network continuously monitoring earthquakes activity and reporting earthquakes. However, the spatial resolution of earthquake reported by BMKG is limited by its routine earthquake report mission and unable to resolve any large earthquake sequence (Fig. 2a). Another available earthquake data came from the International Seismological Centre (ISC), which was set up in collecting, archiving, processing and distributing the definitive summary of worldwide seismicity. The ISC earthquake relocation process used seismic data from all available seismic stations and later phases of all available seismograms, it may provide a regular processing result with high spatial resolution of regional seismicity. However, the ISC relocation requirement of event magnitude is usually higher than the BMKG used in the study area. Consequently, the number of ISC relocated events are smaller than the BMKG reported events (Fig. 2b).

Meanwhile, there is an option to reanalyze the Sumatra subduction zone earthquakes which data provided by the BMKG seismic network and employed recent developed new earthquake location method. In this study, by taking the advantage of high station and event density, we relocated all earthquakes recorded by the BMKG stations from 15 April 2009 to 29 July 2011 (28 months), to enhance the spatial resolution of seismic activity of these earthquake sequences occurred within this period and evaluated the relationship of seismicity pattern and slab geometries. Despite of significant finding about the rupture behaviors of those three large events have been reported, the characteristics of its aftershock sequences, the relationship of major earthquakes and the structure morphology of this active plate boundary, and its mechanism for generating large tsunamis are poorly understood (McCloskey et al. 2010; Bilek et al. 2011; Waldhauser et al. 2012; Tsang et al. 2015). The analysis of this study may provide a new insight or confirm the already proposed seismicity model and its seismotectonic implications.

\section{SEISMOTECTONIC BACKGROUND}

Sumatra subduction zone is considered as result of a large-scale plate convergence (Fig. 1). The Australian plate is obliquely plunged beneath the Eurasian plate with convergence rate varies along the trench between
50 - $70 \mathrm{~mm} \mathrm{yr}^{-1}$ from north to south (Barber et al. 2005). The plate convergence is accommodated by a dip-slip component on the subduction interface known as the mega thrust and a right-lateral strike-slip component on the Sumatra Island known as the Sumatra Fault Zone (SFZ) (Sieh and Natawidjaja 2000; Natawidjaja et al. 2004; Collings et al. 2012). In the oceanic plate, a series of Fracture Zone (FZ) with left lateral strike slip movement, were found reactivated and influence the seismicity distribution at the subduction zone (Deplus et al. 1998; Barckhausen 2006; Delescluse and Chamot-Rooke 2007; Sibuet et al. 2007; Lin et al. 2009). The most hazardous and tsunamigenic region is located along the Sumatra accretionary prism, where several trench parallel thrust and splay faults has been identified and it were found responsible for generating tsunami (Sibuet et al. 2007; Lin et al. 2009; Lay et al. 2011). Moreover, there is a seismic gap region at the Mentawai segment of the megathrust that until now have not yet relaxed (see Fig. 1 for the location) (Konca et al. 2007; Chlieh et al. 2008; Prawirodirdjo et al. 2010).

Historically, large earthquakes have repeatedly occurred along the Sumatra subduction zone (Fig. 1). The Padang earthquake with magnitude Mw 7.6 occurred on 30 September 2009. This event located at $60 \mathrm{~km}$ west-northwest Padang city, West Sumatra. The earthquake was occurred within the deeper portion of the subducted oceanic plate at $80 \mathrm{~km}$ depth by an unusual oblique-reverse rupture (McCloskey et al. 2010; Wiseman et al. 2012). The 6 April 2010 Banyak Island earthquake with magnitude Mw 7.8 was found as a slow slip event and only released a small portion of accumulated stress where other portion of this segment already ruptured and released the accumulated stress during the $2005 \mathrm{Mw} 8.6$ Nias earthquake (Konca et al. 2007; Tsang et al. 2015). The 25 October 2010 Mentawai tsunami earthquake is the only event, which accompanies significant tsunami in this area after the 2004 Mw 9.2 great Sumatra-Andaman earthquake. This Mentawai tsunami earthquake ruptured at seaward side of Pagai islands of the Mentawai fault zone offshore of Sumatra and it is categorized as a shallow megathrust rupture (Lay et al. 2011). Actually, not only those subduction events but several great earthquakes have occurred within the fracture zone at the northeastern Indian Ocean plate (Fig. 1). On 11 April 2012, two great earthquakes of magnitude Mw 8.6 and 8.2 occurred within the ocean plate and have marked as a very special case of its large strike-slip faulting (Meng et al. 2012; Yue et al. 2012).

\section{SEISMIC DATA}

The earthquake data that we analyzed in this study are P-wave arrival times from stations of the BMKG seismic network. Within the 28 months period (from April 2009 and July 2011), we received a total of 2447 events located by the BMKG data center (Fig. 2a). The shallowest earthquake 
in this dataset is $10 \mathrm{~km}$ in depth, while the deepest one is $629 \mathrm{~km}$. To reduce error, we only use the earthquakes with depth less than $200 \mathrm{~km}$ and magnitude greater than 2 reported by BMKG. The seismograph networks were spatially distributed along Sumatra region (Fig. 2a). The total amounts of station in this region are 48 stations. These stations were join-operated between several agencies; BMKG-CBTO (Indonesian), JISNET (Japan), GFZ (German), and CEA (Chinese). Most of the station seated along Sumatra Fault Zone, meanwhile several stations at forearc Islands. In comparison to the ISC catalogue within the same time period, only 220 events have been reported (Fig. 2b). The spatial distribution of earthquakes based on limited events has shown huge gap within those events. On the other hand, based on dense local observations, the BMKG data set provided more events than that listed on the ISC catalogue. However, BMKG routinely located events presented a scatter pattern and some of them uncorrelated to slab geometries (Fig. 2a). Hence, to study earthquake sequences of three large events, it is necessary to reprocess them for further analysis. In this study, we dedicated to relocate BMKG catalogue events based on the double-difference relative location method (Waldhauser and Ellsworth 2000) and it allowed us to examine these three large subduction earthquake sequences in detail.

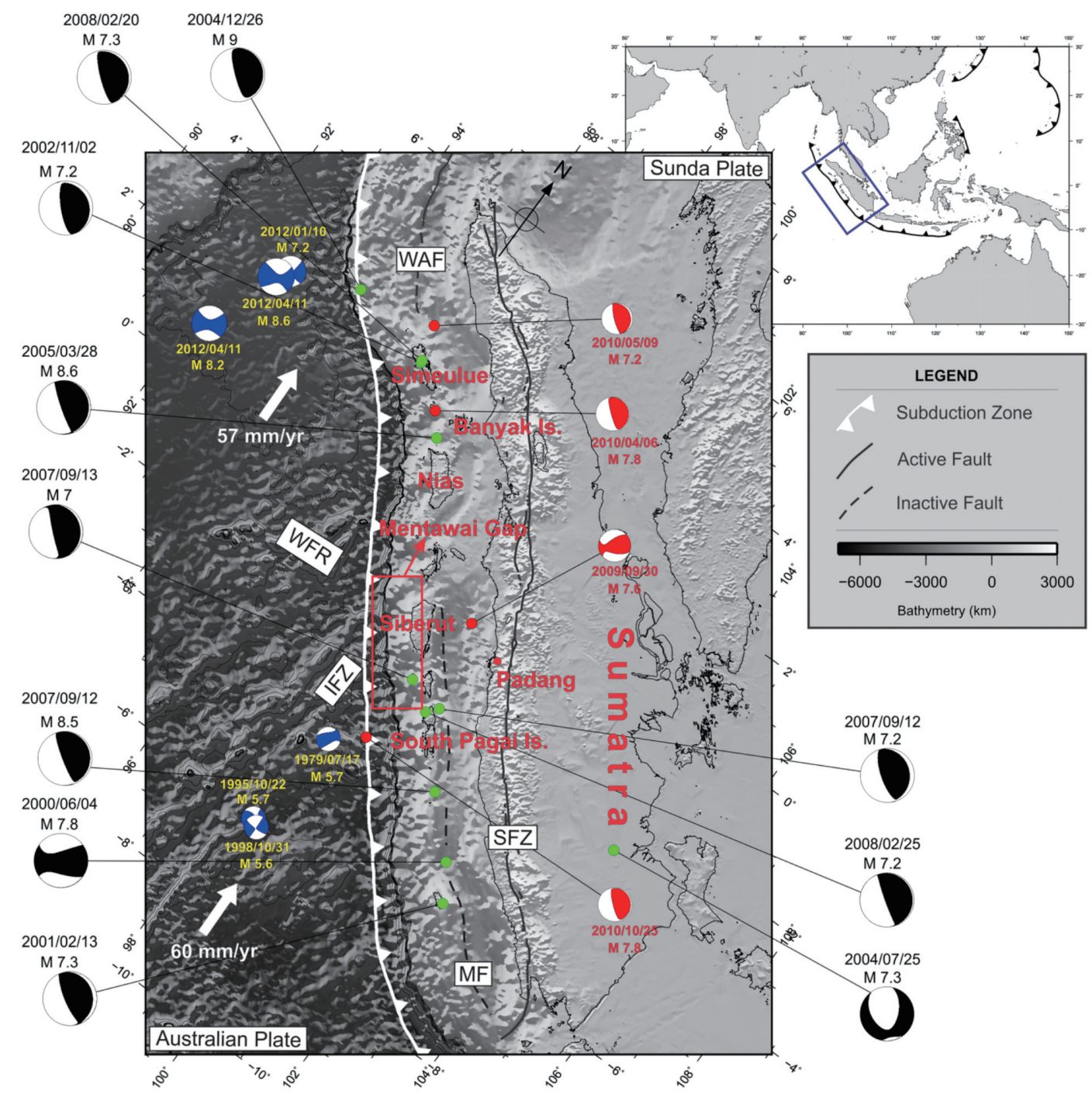

Fig. 1. Tectonic setting of the Sumatra subduction zone. Background map: The Sumatra Island is shown by the blue rectangle and it is located at the southwestern edge of Southeast Asian margin as well as one of the biggest island of Indonesian archipelago. Foreground map: The figure has been rotated to trench parallel. SFZ: Sumatra Fault Zone; WAF: West Andaman Fault; MF: Mentawai Fault; WFR: Wharton Fossil Ridge; and IFZ: Investigator Fracture Zone. Convergence rate of the subducting Australian oceanic plate beneath the Sunda continental plate from Sieh and Natawidjaja (2000). White line with tooth represents the megathrust fault boundary extracted from the top of the Slab 1.0 by Hayes et al. (2012). The forearc Islands that discussed in this study are shown by text. Dashed lines of the MF and WAF are the portions of active faults with uncertainty. The beach balls were retrieved from the Global CMT catalogue (http://www.globalcmt.org/) with magnitude greater than 7 . The focal mechanism in red color indicated event occurred within the analyzed time period of this study, black color indicated some selected events outside the analyzed time range of this study, blue color indicated events located at the oceanic plate. The Mentawai Gap location is shown by the red rectangle. 

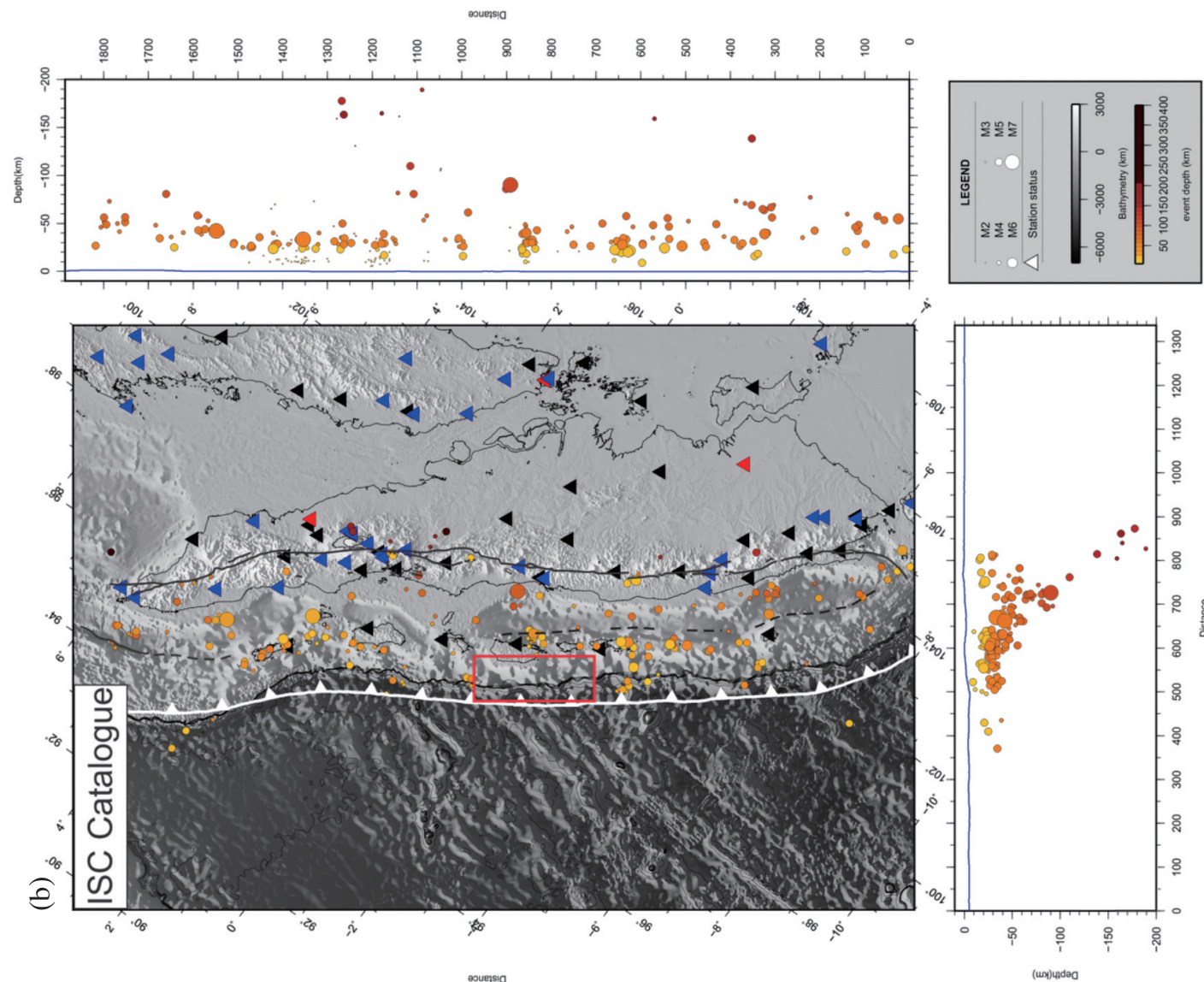

을

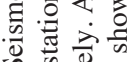

즐 근

을

可 चै चै

일

ف용

혈

.

은 흥 응

记 ป :

尫

Oิ

急完

包命

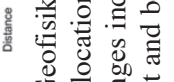

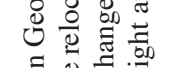

击.

항 吾 흥

웡

自然产家

.0.

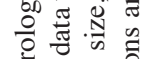

웡

ऐं क्ष
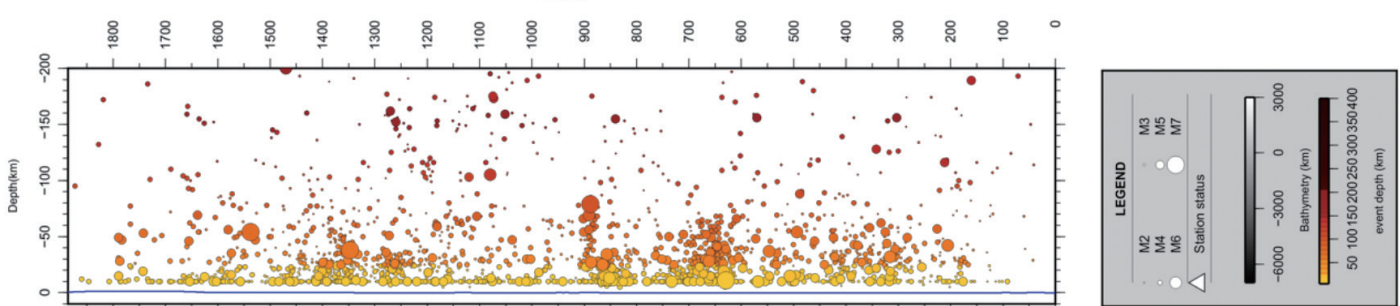

ज्ञ ज्ञ

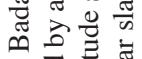

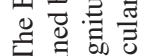

ఏ歌

: 켤

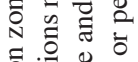

.․ํㄹ

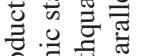
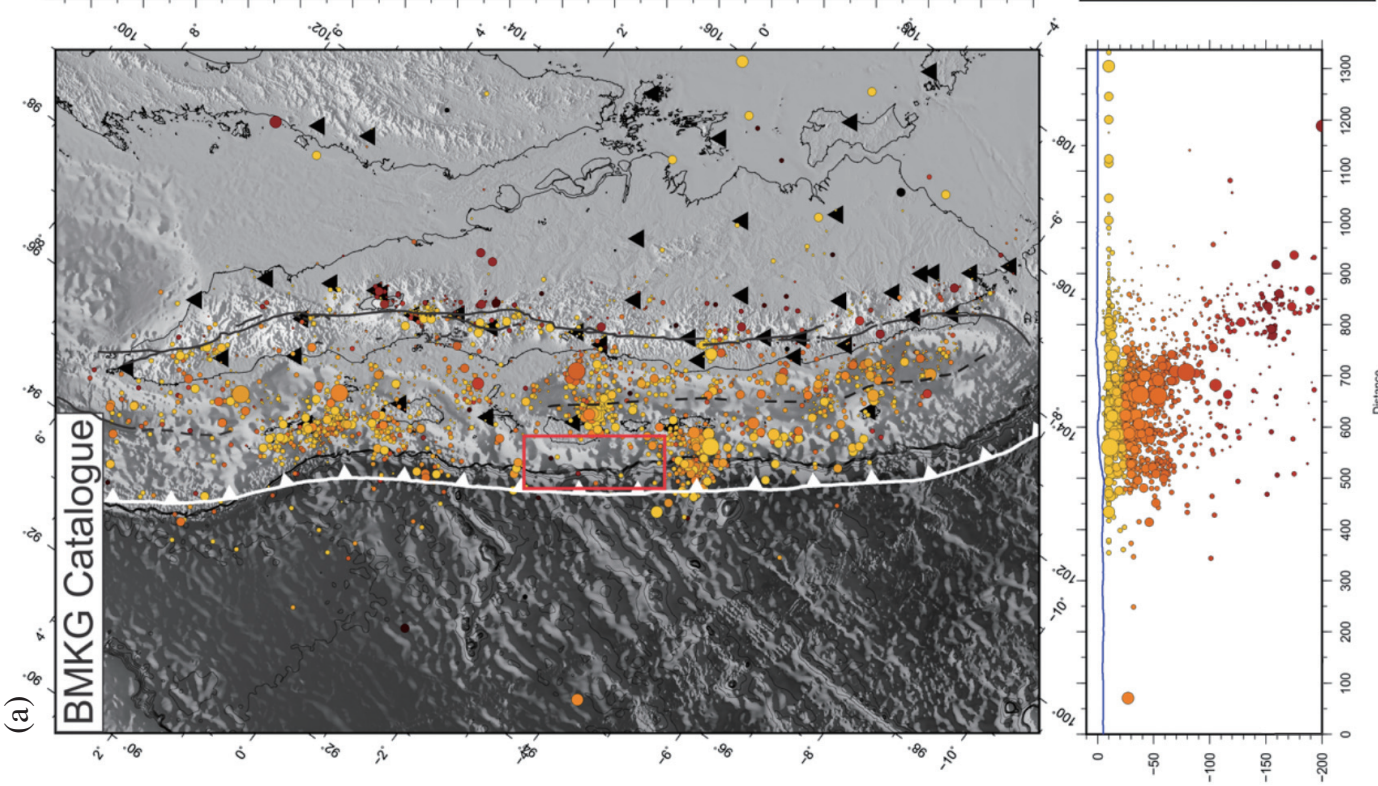

क.

ज्ञ

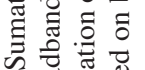

롷음

क

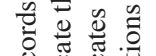

Ð.马

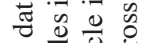

츨

击

踏会

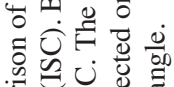

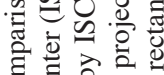

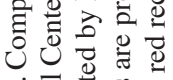

i . 厄ु 


\section{ANALYSIS AND RESULTS}

\subsection{Regional 1-D Model Estimation}

We received the P-wave arrival times of each earthquake and the event catalogue in which each event was located using the AK135 one-dimensional (1-D) velocity model (Kennett et al. 1995). However, the initial relocation by the BMKG still shown an artefact, where some earthquakes appear to lineate at a depth of 10 or $30 \mathrm{~km}$ as shown in Fig. 2a. To improve the accuracy of the hypocentre locations, we need to obtain the preferred regional 1-D velocity model, firstly. For this purpose, we use the VELEST program (Kissling et al. 1994) for velocity inversion. The initial velocity models are composed from some previous studies at this region (Lange et al. 2010; Collings et al. 2012). By combining these initial velocity models, we gained 250 trialed velocity models for the inversion. Selected data of an event only with a minimum of six phases and a maximum azimuthal gap of less than $210^{\circ}$ will be included in inversion analysis. Overall, 864 earthquakes meet these criteria and the preferred 1-D Pwave velocity model obtained from the inversion is shown in Fig. 3a. Beneath $50 \mathrm{~km}$ depth, this model has extended using the model AK135 to depth $200 \mathrm{~km}$.

\subsection{Relocation of BMKG Catalogue Events}

According to the inverted velocity model, we applied the double-difference relative location method (Waldhauser and Ellsworth 2000) for final relocation of the earthquake events. The double-difference algorithm has been implemented in the computer program HypoDD (Waldhauser 2001). The program HypoDD has been extensively tested with data from permanent networks and aftershock arrays around the world to verify its ability to improve the image of seismicity (Rietbrock and Waldhauser 2004; Waldhauser et al. 2012; Shih et al. 2014). The earthquake data of P-wave arrival times collected from stations of the BMKG seismic network have been analyzed in this study based on the HypoDD algorithm. Having an advantage in the huge amount of event and high station density, in this study, to handle the large network to be analyzed by the double difference method, different parameter settings have been tested in this study. After dense testing, some parameters have been decided in this study. We set up the HypoDD relocation with a maximum hypocentral separation of $20 \mathrm{~km}$, a maximum number of neighbors per event are assigned to 10 and we constrain more on the maximum distance between the catalogue linked pairs to $10 \mathrm{~km}$.

The quality improvement of the dataset after the HypoDD relocation is shown in Figs. $3 \mathrm{~b}$ and c. In Fig. 3b (left) for the magnitude coverage, the blue and red dots is shown the data before and after HypoDD relocation, respectively. The completeness data coverage is shown by the magnitude coverage. It is clearly shown that the earthquake events that have a magnitude lower then 5 , being removed at about $\sim 50 \%$ of its original counts. This happens due to limited amount of station that able to detect the smaller magnitude events, hence it resulted in a large distance between the event - stations and event - event pairs, that the HypoDD consider this type of events are either out of network events, too scattered or even weakly linked, and that its removed from the output. The Root-Mean Squares (RMS) time residual are greatly reduced, with the increasing amount of data that has a RMS values between $0-1$ second(s), with its maximum density at $0.4 \mathrm{~s}$ (red rectangle), rather than the data before performing HypoDD which has the RMS spread through $\sim 4 \mathrm{~s}$, with its maximum density at $1 \mathrm{~s}$ (blue rectangle), as it is shown in Fig. 3b (center). Figure 3b (right) is shown the changes of the origin time, which indicates that most of the event being advanced and delayed at $+/-1 \mathrm{~s}$ to its origin time. The events origin time difference indicate that some event might had been relocate with having less number of neighboring events however the link between the events to the station and its events pair is enough, that will have resulted in advanced origin time of the events. Likewise, the events that having more number of neighboring events might increase the amount of cluster, with that condition, the HypoDD will delayed more time so that each pair can be linked, which at the end will resulted in delayed origin time of the events. Figure $3 \mathrm{c}$ is shown the offset of events between before and after HypoDD relocation, horizontally (between north-south and east-west offset) and vertically (between north-south offset and depth, and east-west offset and depth). There was no particular pattern between these offsets, however the largest concentration of offsets is within $5 \mathrm{~km}$ either horizontally and vertically. Although earthquake location using the HypoDD algorithm may reject some uncorrelated events, it is found that the relocated catalogue presented the similar temporal distribution of the original BMKG catalogue as it is shown in Fig. 4, moreover it is clearly shown in Fig. 3b (left) for the magnitude coverage, only smaller magnitude event did not survive the HypoDD relocation, and that the larger magnitude resulted in almost the same number of events. Smaller magnitude of earthquake may indicate a minor structure being active, while the large magnitude may indicate for the major ones. In this study, 1094 events were successfully relocated (Fig. 4), additionally, the readers could further assess the RMS event distributed based on its location along the margin by seeing the Fig. S1 of Supplementary Data. After the relocation, the distribution of earthquakes appeared to be more concentrated around the three main large earthquakes as it is shown in Fig. 5. The perpendicular and parallel cross sections view throughout the subduction zone, shows a distinct feature of the subduction earthquake. Comparison of relocated earthquake distribution of this study (Fig. 5) with previous reports by BMKG and ISC catalogues (Figs. 2a and b), it presented spatial clustered seismicity distribution and the enhanced shape of subduction slab than that plotted from the 


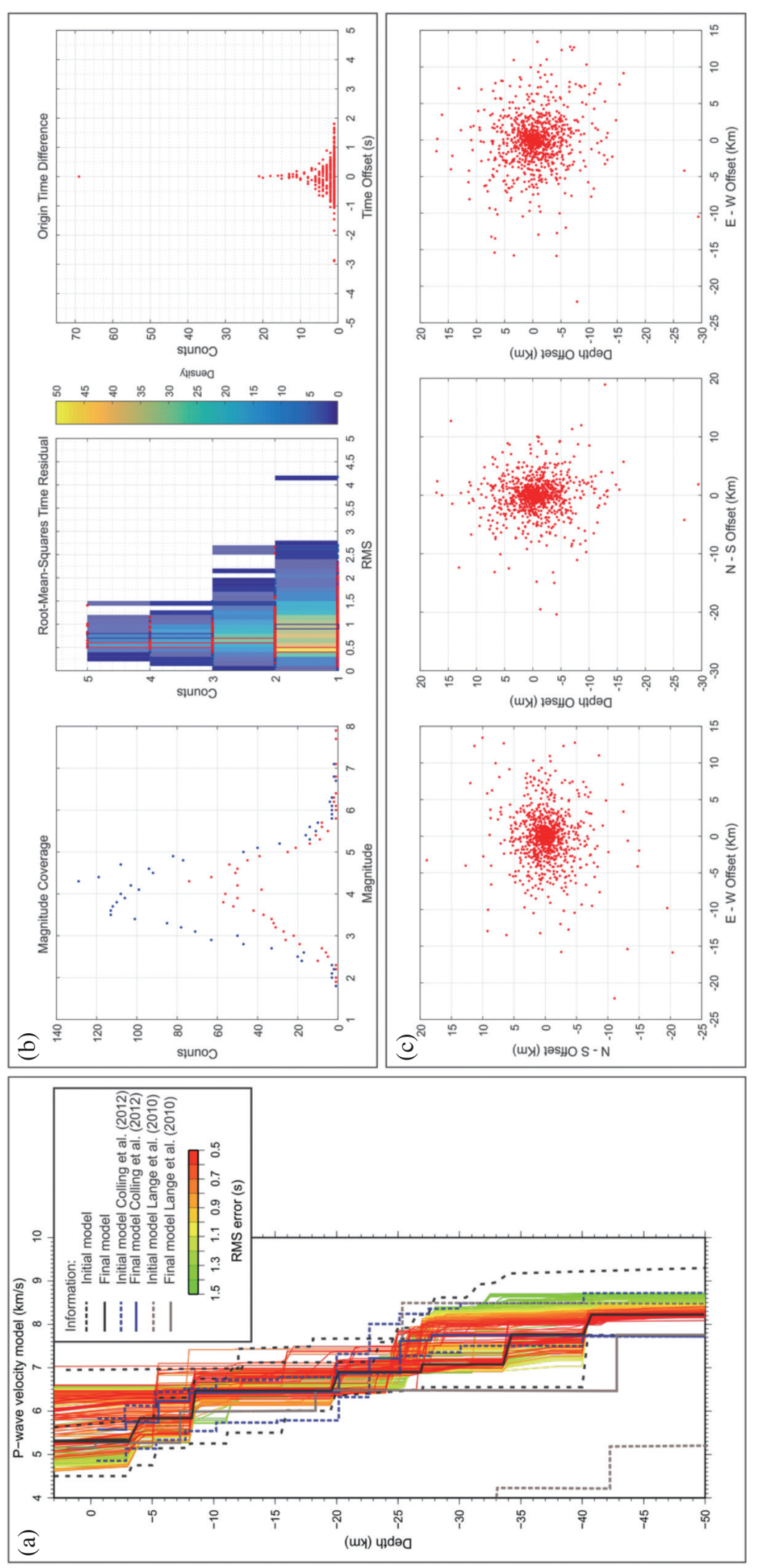

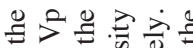

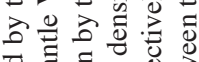
马ี

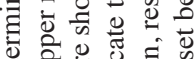

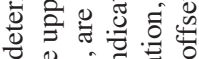
ิิ) 产过号它

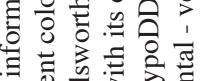

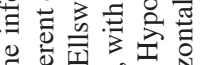

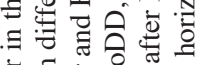

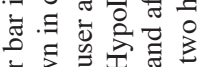

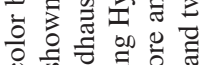

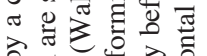

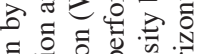

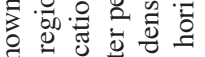

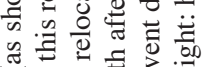

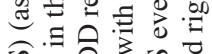

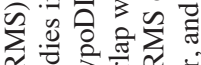
올 us की

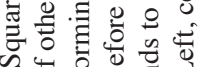
फ

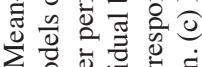

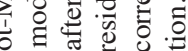
점

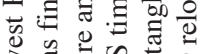

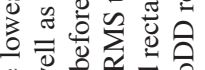

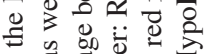

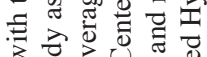

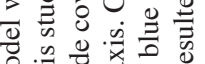

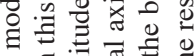

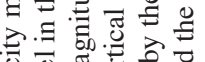

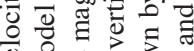

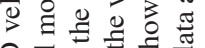

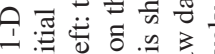

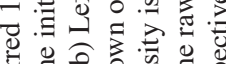

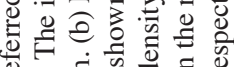

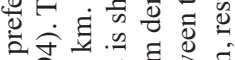

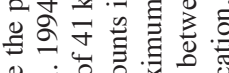

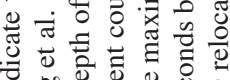

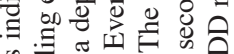

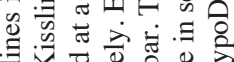

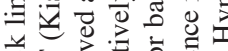

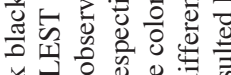

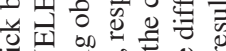

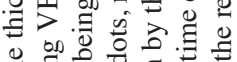

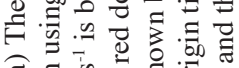
త)

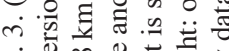

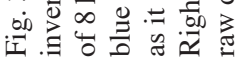



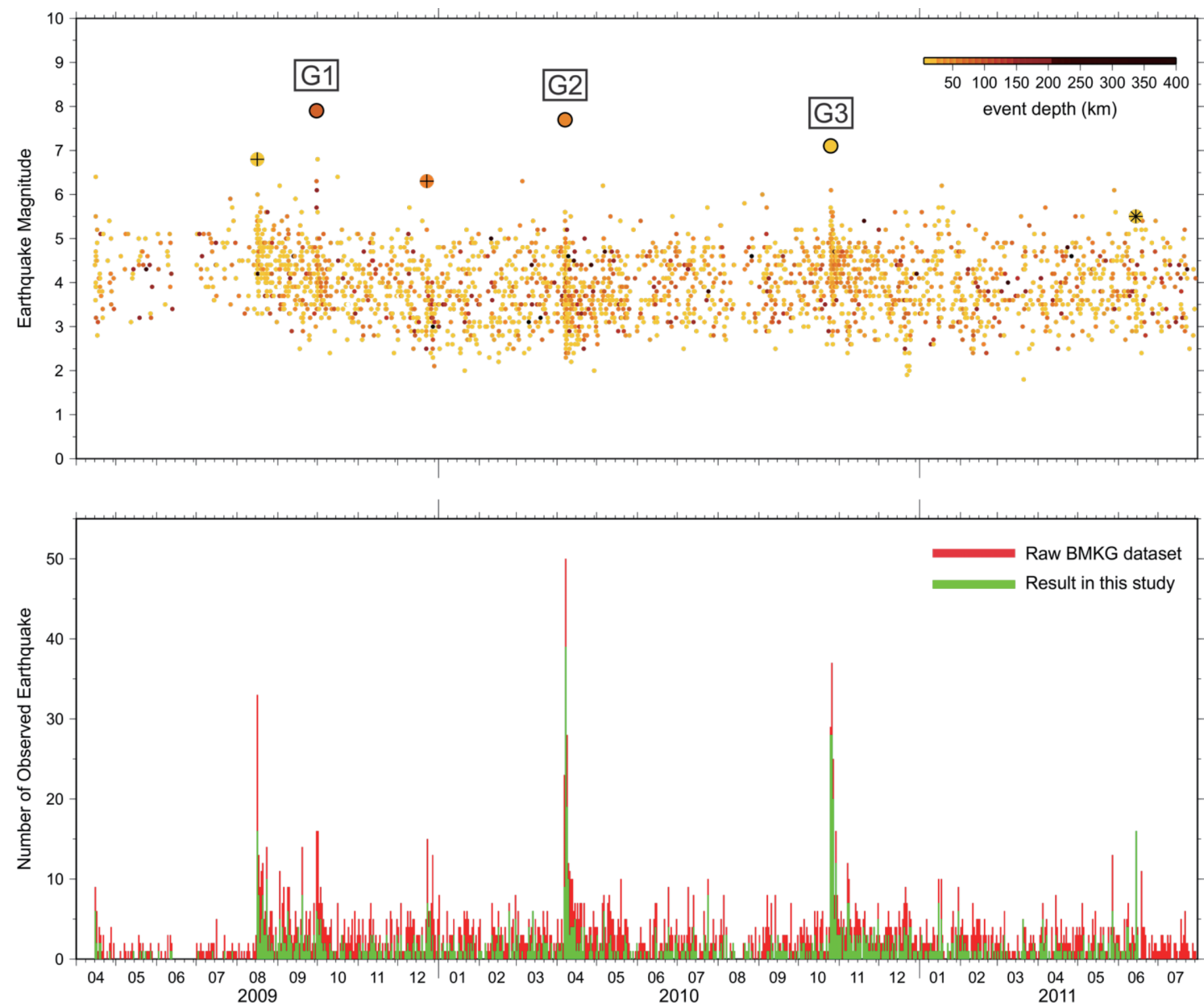

Fig. 4. Top: the time series of earthquake occurrence. Event magnitude shown on the vertical axis. Event color indicated its depth (shown by a scale bar on the upper right corner of figure). The earthquake sequences discussed in this study are shown by the G1, G2, and G3, respectively. The circles with cross or star symbol denoted three other shallow earthquakes discussed in this study. Bottom: the event number from the BMKG catalogue and relocated earthquakes of this study that are shown by the red and green histogram, respectively. 


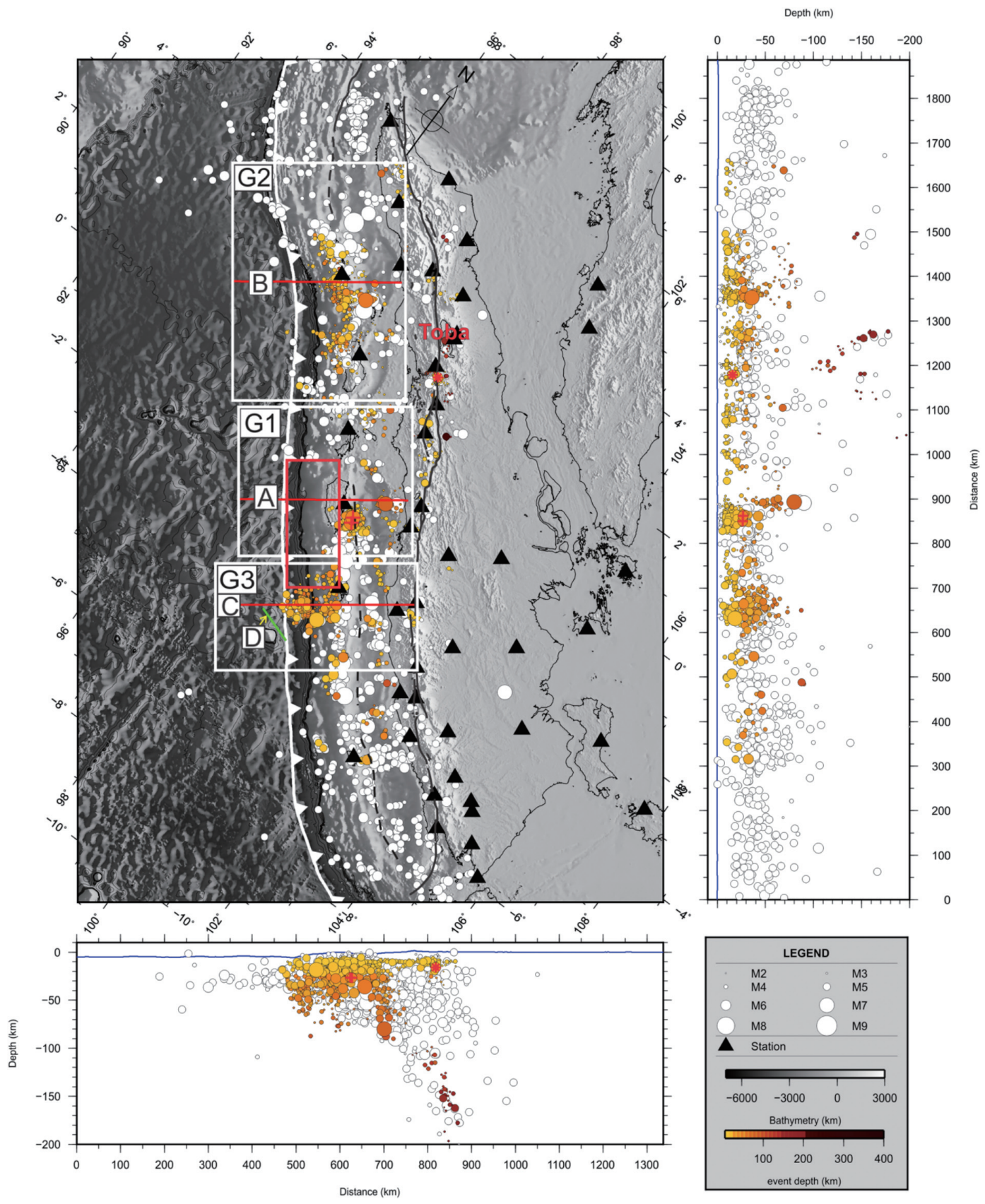

Fig. 5. The spatial distribution and cross sections of relocated earthquakes after applying the HypoDD that being feed by the preferred 1-D velocity model in Fig. 3a. The background seismicities shown in white circle are the available earthquake events from the reviewed ISC catalogue during 1 January 1993 to 31 July 2011 at this region. Three boxes of concentrated earthquakes correspond to the three main events during the data period. The G1 correspond to the 30 September 2009 Mw 7.6 Padang earthquake, G2 correspond to the 7 April $2010 \mathrm{Mw} 7.8$ Banyak Island earthquake, and G3 correspond to the 25 October $2010 \mathrm{Mw} 7.8$ Mentawai tsunami earthquake. Three cross sections being made with SW-NE orientation, as indicated by solid red lines with text A, B, C and another cross section with W-E orientation as indicate by solid green line with text D. The Mentawai gap is shown by the red rectangle. Symbols of circle with cross or star are epicenters of other small earthquake sequences as shown in Fig. 4. 
BMKG and ISC catalogues. This indicates an improvement of hypocenter determination by using the obtained velocity model and the HypoDD relocation. For better interpretation, we separate these earthquakes into three groups following three large earthquakes occurred during this period (Fig. 5). Thus, Group 1 (G1) is located around the Padang earthquake, Group 2 (G2) is located around the Banyak earthquake, and Group 3 (G3) is located around the Mentawai tsunami earthquake. In this study, each group events are plotted as enlarged maps as shown in Figs. 6 - 8 .

The distribution of G1 earthquakes are separated by two groups. One located at southeastern coast of Siberut island within $99.25^{\circ}-99.7^{\circ} \mathrm{E}$ and $2.25^{\circ}-1.6^{\circ} \mathrm{S}$, and the other one located at western offshore of Padang region within $99.7^{\circ}-99.9^{\circ} \mathrm{E}$ and $0.7^{\circ}-0.8^{\circ} \mathrm{S}$ (Fig. 6). The epicenter of the Padang earthquake is located $60 \mathrm{~km}$ west-northwest of the city. Our result shows that aftershocks distributed in small amount close to the main shock and quickly decay with time (Fig. 4). Instead of close to the main event, other events are concentrated at the western edge portion of the forearc basin, southern coast of Siberut island (Fig. 1). Two earthquake sequences with main shock magnitude less than 7 were identified to occur within this portion (circle with cross symbols in Figs. 5 and 6), one before and the other after the Padang earthquake (Fig. 4). Both major events have epicenters near the plate interface (Fig. 6). This plate interface has been defined by the top boundary of slab based on the global slab model named the slab 1.0 (Hayes et al. 2012).

Earthquake distribution of G2 showed that major aftershocks concentrated at western offshore of the Banyak Islands at $96.2^{\circ}-96.8^{\circ} \mathrm{E}$ and $1.95^{\circ}-2.3^{\circ} \mathrm{N}$ with shallow depths. It is about $25 \mathrm{~km}$ separation from the main shock to

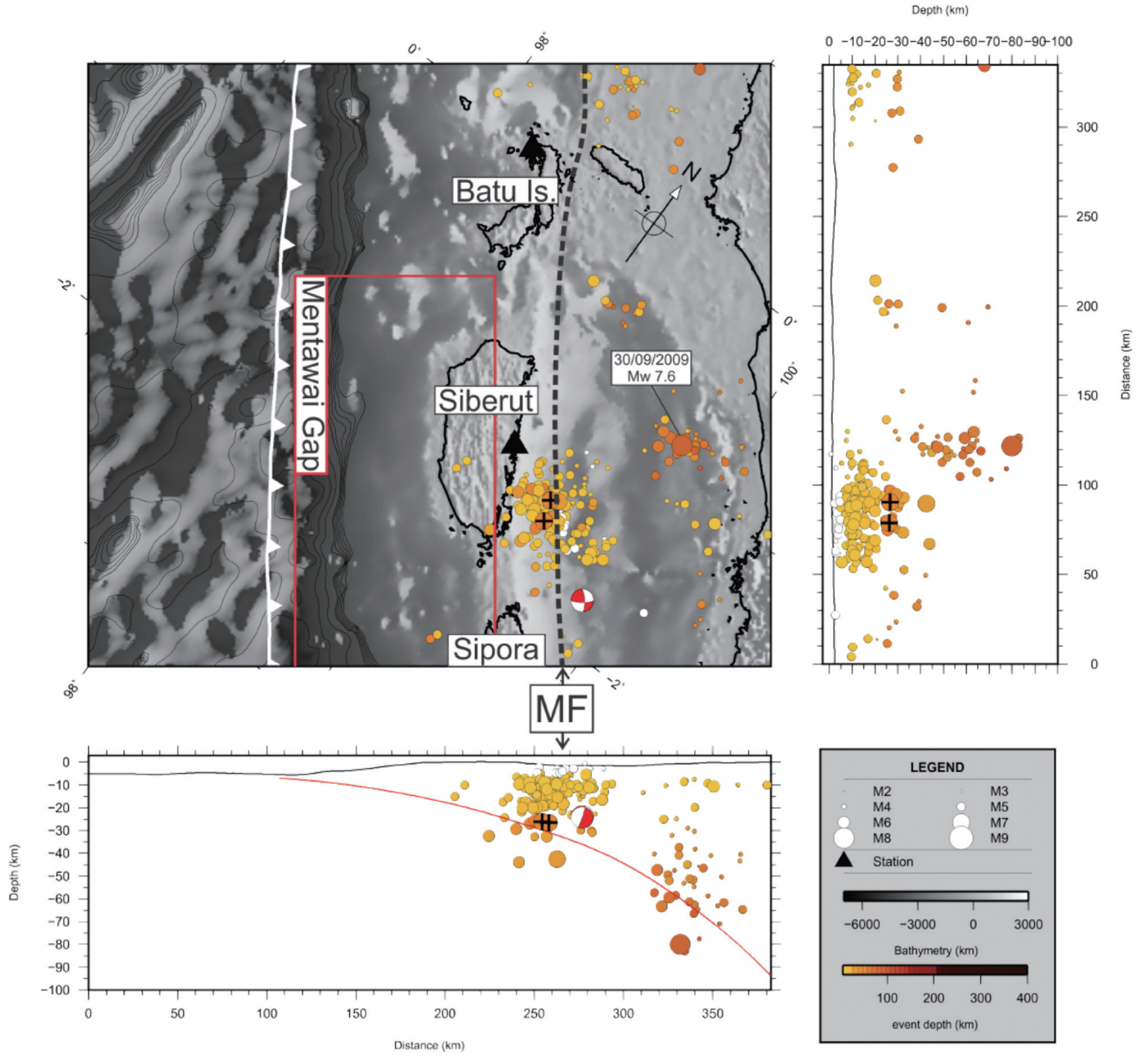

Fig. 6. An enlarged map of event distribution of the Padang earthquake sequence (G1) in Fig. 5 and its vertical cross sections which oriented on both parallel and perpendicular slab directions. White line with tooth represents the megathrust fault boundary. The main event and island names discussed in this study are labeled with text. The Mentawai gap region is shown by the red rectangle with label. MF: Mentawai Fault. The distance of cross section is defined as zero at the map lower left corner. The solid red line on the slab perpendicular cross section represents the plate interface. This plate interface has been defined by the top boundary of slab based on the global slab model named the slab 1.0 (Hayes et al. 2012). Two symbols of circle with cross are epicenters of two small earthquake sequences as shown in Fig. 4. The beach ball was retrieved from the Global CMT catalogue (http://www.globalcmt.org/). 


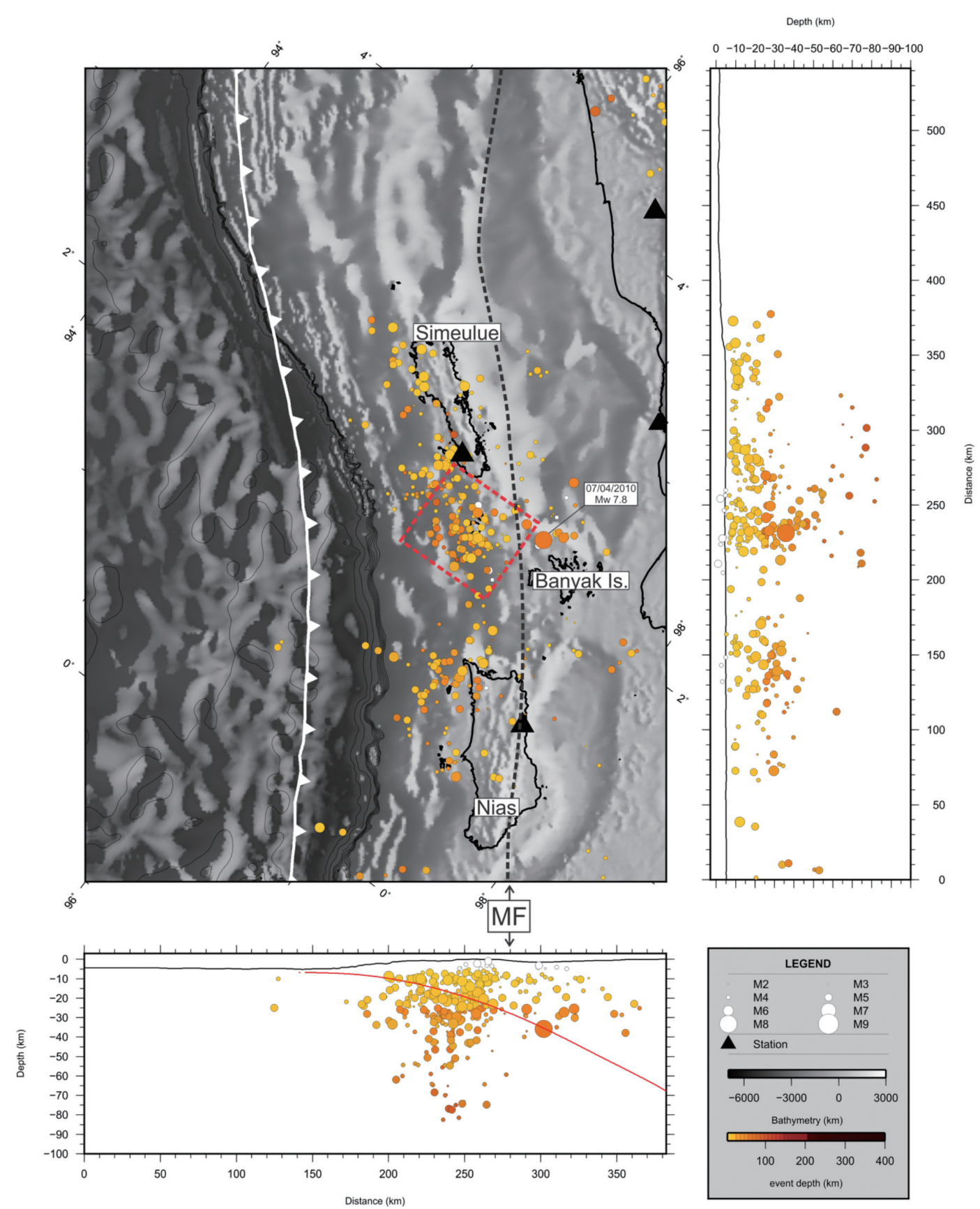

Fig. 7. An enlarged map of event distribution of the Banyak Island earthquake sequence (G2) in Fig. 5 and its vertical cross sections which oriented on both parallel and perpendicular slab directions. The dashed red box indicates the aftershock events. Symbol definition in this figure is the same as Fig. 6 as well as the island names and main event are labeled by text. 

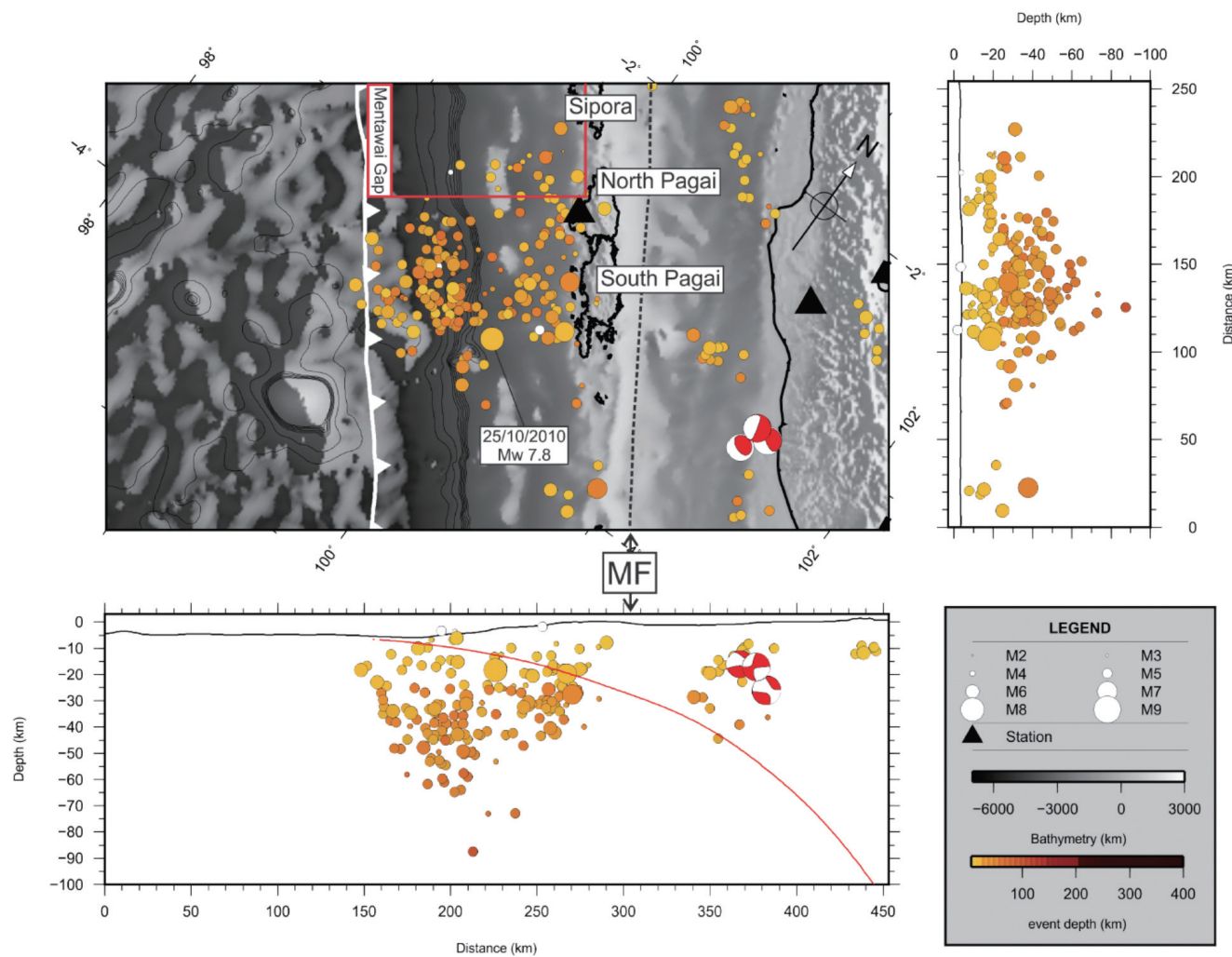

Fig. 8. An enlarged map of event distribution of the Mentawai tsunami earthquake sequence (G3) in Fig. 5 and its vertical cross sections which oriented on both parallel and perpendicular slab directions. Symbol definition in this figure is the same as Fig. 6 as well as the island names and main event are labeled by text. The beach ball was retrieved from the Global CMT catalogue (http://www.globalcmt.org/).

its east (dashed red square box in Fig. 7). A clear north-south trending earthquake activity concentrated at $97^{\circ}-97.25^{\circ} \mathrm{E}$ and $1^{\circ}-1.93^{\circ} \mathrm{N}$ is observed at southern side of the main event. Some events occurred and concentrated at the northwestern and southeastern coast of Simeulue island with a lesser event observed at the central portion of this island.

On G3, most of earthquakes are located at $99^{\circ}-100^{\circ} \mathrm{E}$ and $2^{\circ}-4^{\circ} \mathrm{S}$, distributed close to the Mentawai tsunami earthquake main event and at the forearc basin. The aftershocks were observed to distribute at northwestern direction of the main event, at the deformation front, at the accretionary wedge and at western edge offshore of the South Pagai island (Fig. 8). Major aftershocks occurred at western side of the main shock and close to the trench. Only a small portion of concentrated events is observed close to the eastern edge of the forearc basin at around $100.5^{\circ}-101^{\circ} \mathrm{E}$ and $2.8^{\circ}-3^{\circ} \mathrm{S}$.

Far from the plate boundary, some events occurred along the Sumatra fault zone included one shallow earthquake sequence with small main shock (circle with star symbol in Figs. 4 and 5) and its focal mechanism shown as a strike-slip faulting from the global moment tensor report (http://www.globalcmt.org/). Furthermore, some deep earthquakes (with depth near $150 \mathrm{~km}$ ) individually occurred beneath the volcano Toba, northern Sumatra (Fig. 5) with limited aftershocks were observed, although regional seis- mic activities in this region are usually following large earthquakes (Fig. 4).

\subsection{Seismic Cross Sections}

The event relocation process of this study has enhanced the spatial grouping of earthquake distribution (Fig. 5). It provided an opportunity to link earthquake activity to the active fault geometry. However, it is hard to manually identify a possible fault orientation from those concentrated seismicity directly. To quantitative estimation of fault orientation, in this study, we employed a statistical procedure to evaluation. Thus, based on the preliminary projected lineation and/or grouping features of earthquakes in surface map or vertical cross section, we selected the candidate concentrated events. The width of the projection is set as large as the width of each group, additionally, we examine the projection result in order to make sure that all earthquakes within the group region are all being included. Then a linear polynomial fit test, which is used to observed the linear fitting, takes the following form:

$\mathrm{y}=\mathrm{p} 1(\mathrm{x})+\mathrm{p} 2$

Where, $\mathrm{x}$ and $\mathrm{y}$ are the earthquake location at its distance 
along the cross section horizontally and vertically, while $\mathrm{p} 1$ and $\mathrm{p} 2$ are the slope and $\mathrm{y}$-intercept at $95 \%$ confidence interval, respectively. The $\mathrm{p} 1$ variable is the slope of the line and control its steepness. Those calculations were performed by using cftool: a curve fitting toolbox in MATLAB software. From Eq. (1) we could calculate the dipping angle of each lineation of earthquake by using the following equation:

$\mathrm{D}=\left(\frac{180^{\circ}}{\pi}\right) \times \tan ^{-1}(\mathrm{p} 1)$

where $\mathrm{D}$ is the dipping angle in degree. Based on this estimation procedure, the coefficient of determination ( $\mathrm{R}$ square), degree-of-freedom adjusted coefficient of determination (R-square) and root mean squared error (RMSE) are reported in each fitting calculation (Mathworks 2017). The $\mathrm{R}$-square is the coefficient of determination. Which means, its value is shown how well the linear fitting could predict the data fitting, and its value falls between 0 and 1 . The higher value of R-square means the better fitting to the observed data. While, the adjusted R-square is the refinement of the fitting, if the fitting being included with the higher order polynomials, which yield a better fitting result are expected. A smaller adjusted R-square result may indicate a more reliable estimate of the polynomial model to predict the observed lineation.

In this study, a combined vertical cross section of three large earthquake sequences oriented on perpendicular slab direction (thus, SW-NE orientation) has been made and shown in Fig. 9. After above statistical analysis, some grouping events can be identified as high confident lineations (summarized in Table 1 and drawn in Fig. 9). The identified faults (F1, F2, and USP) show higher confidences than FZ1, FZ2, and F3. Those values provided a useful indication for our further interpretation. In Fig. 9, the location of horizontal distance zero point of each profile is defined according to the left boundary location of each group in Fig. 5 .

Projected G1 earthquakes along profile A (Fig. 5), the cross section is shown in Fig. 9a. It is found that most of the earthquake occurred within the accretionary wedge and above the modeled plate interface of slab 1.0 (Hayes et al. 2012) which was shown as solid red line along the cross section. Grouped earthquakes concentrated at distance 230 - $290 \mathrm{~km}$ along the profile with depth shallow than $45 \mathrm{~km}$. The other group of observed seismicity is located at distance between 315 - $370 \mathrm{~km}$ (Fig. 9a). Most of events of this group occurred above the plate interface and within the mantle wedge of the continental crust where the Padang earthquake being observed at about $80 \mathrm{~km}$ depth inside the oceanic slab and near the bottom of this grouped events. From the zoomed view of section A (on left portion of this profile), the observed earthquakes are grouped (after statistical analysis) as three distinct lineations (solid black lines). The pattern of lineation mimics a series of splay type faulting. The dipping angle of $\mathrm{f} 1, \mathrm{f} 2$, and $\mathrm{f} 3$ in Fig. 9a were determined as $31^{\circ}$, $50^{\circ}$, and $57^{\circ}$, respectively. The uppermost extension of $\mathrm{f} 2$ and $\mathrm{f} 3$ to ocean bottom correspond closely to the continental slope sites that indicated by arrows on the bathymetry. The lineation of $\mathrm{f} 2$ and $\mathrm{f} 3$ are found overlap (similar lineations were found) with the recently studied earthquake sequence by Wang et al. (2018). The blue and red circles in Fig. 9a section A were correspond to the 2005 and 2009 earthquake cluster identified from their study.

Projected G2 earthquakes along profile B, the cross section is shown in Fig. 9b. A concentration of earthquake is observed at the accretionary wedge ranging from 170 $270 \mathrm{~km}$. Those events distributed within the accretionary wedge, oceanic crust and mantle. The Banyak Island earthquake is located at about $300 \mathrm{~km}$ distance along the profile with depth of about $37 \mathrm{~km}$. A lineation of earthquakes is identified and it is shown by the zoomed view on the left of this section. It has a dipping angle of $29^{\circ}$, and plausible as the observed activity of the upper splay fault (USF) (Lin et al. 2009).

There are three portions of seismicity that being observed along the $\mathrm{C}$ profile from $\mathrm{G} 3$ earthquakes projection. The cross section is shown in the Fig. 9c. The first portion located at a distance of $150-215 \mathrm{~km}$ along the profile, which shows that the observed earthquakes concentrated within the subducted plate. The second portion is located at a distance of $220-280 \mathrm{~km}$ along the profile where the observed seismicity located within the oceanic crust and at the modeled plate interface of slab 1.0 (Hayes et al. 2012). The third portion of the seismicity is located at a distance of 340 - $390 \mathrm{~km}$ distance along the profile. However, this lineation cannot be confirmed because the event was randomly distributed (ungrouped) within a range of more than $200 \mathrm{~km}$ distance wide along the horizontal plane (Figs. 5 and 8).

The first portion events (along the $\mathrm{C}$ profile) have been projected perpendicular to the direction of its nearby Australian plate fracture zone, i.e., along the profile D in Fig. 5. The cross section is shown as the zoomed view box on the left of this section (names as section D in Fig. 9c). After statistical analysis, with at least, two almost vertical oriented lineations at $10-50 \mathrm{~km}$ depth were identified and shown in the section D of Fig. 9c. The dipping angle is determined as $87^{\circ}$ and $83^{\circ}$ for the FZ1 and FZ2 in the section D, respectively. The locations of the FZ1 and FZ2 extended to the ocean bottom surface on the bathymetry profile are shown by the black arrows in the section D.

\section{DISCUSSION}

The 26 December 2004 Sumatra-Andaman giant earthquake has ruptured a more than $1000 \mathrm{~km}$ long portion of plate boundary with large fault slips of $10 \mathrm{~m}$ or more (Ishii et al. 2007; Huang et al. 2011). It produced the most devastating 

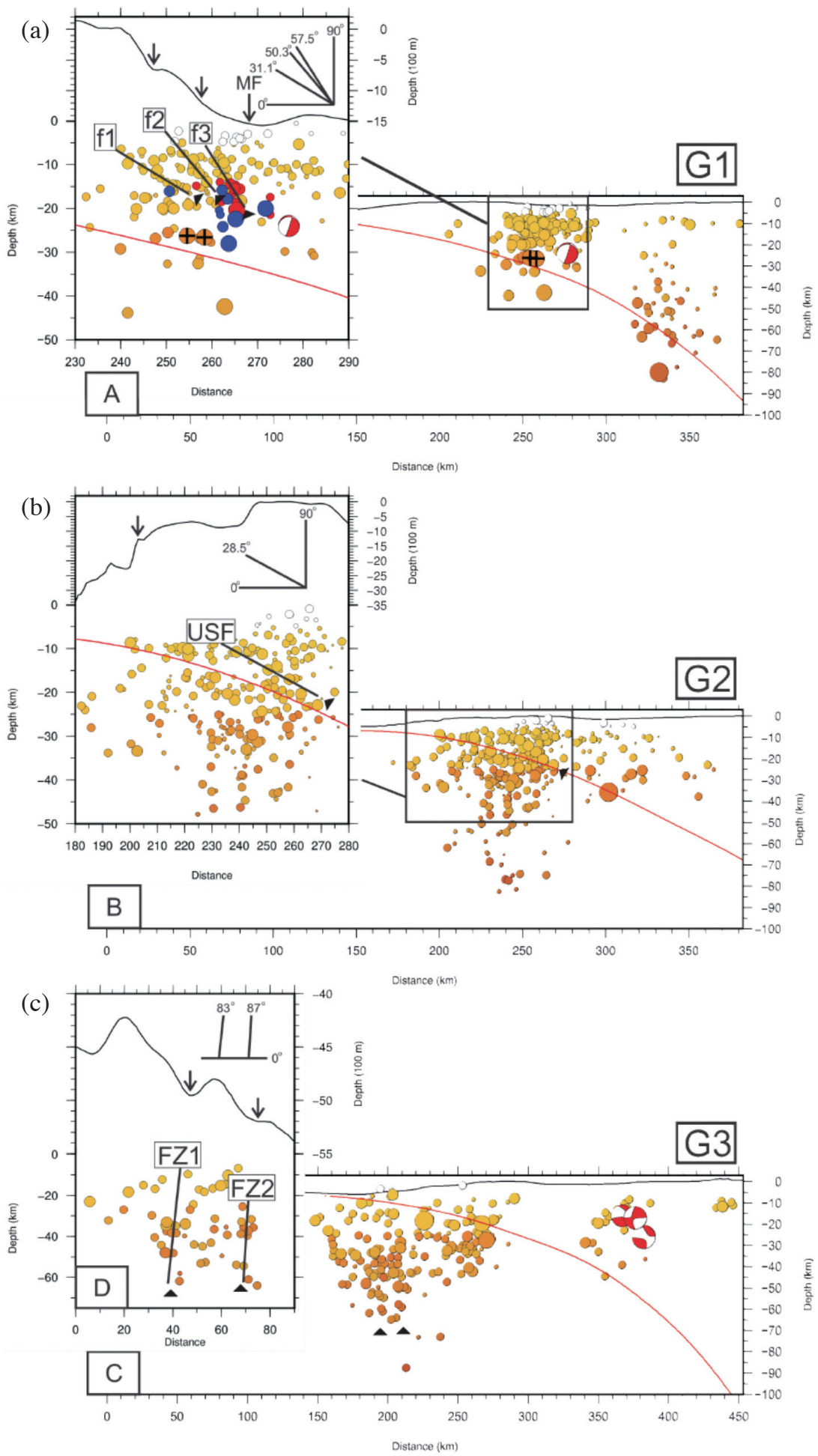

Fig. 9. Cross section: (a) A and its zoomed view (top) with the earthquake clusters studied by Wang et al. (2018) overlapped with the result in this study, are shown in red and blue circle, respectively; (b) B and its zoomed view; (c) C and D (bottom). The zoomed view location is indicated by the black rectangle along the profile, and identified earthquake lineation is shown by black triangle. The solid red line indicates the plate interface defined by the model of slab 1.0 (Hayes et al. 2012). The polynomial linear fit is shown in solid black line and corresponds to each fault that indicated by text. The dipping angle is shown in degree and black arrows show the approximate location of the fault along the profile bathymetry. 
Table 1. Main statistics of the polynomial linear fit of earthquake lineation with $95 \%$ confidence bonds.

\begin{tabular}{c|c|c|c|c|c|c}
\hline \multirow{2}{*}{ Identified Lineation } & \multicolumn{2}{|c|}{ Coefficients } & \multirow{2}{*}{ R-square } & Adjusted R-Square & \multirow{2}{*}{ RMSE (km) } & \multirow{2}{*}{ Dip angle $\left(^{\circ}\right)$} \\
\cline { 2 - 6 } & P1 & P2 & & & & \\
\hline F1 & -0.6042 & 137.7 & 0.9405 & 0.9351 & 0.7072 & 31.1404 \\
F2 & -1.205 & 296.9 & 0.7174 & 0.7008 & 2.26 & 50.3116 \\
F3 & -1.575 & 403.1 & 0.3915 & 0.3535 & 3.071 & 57.5877 \\
FZ1 & -0.1071 & 35.05 & 0.1967 & 0.1349 & 2.633 & 83.8869 \\
FZ2 & -0.06082 & 67.53 & 0.1447 & 0.0669 & 2.401 & 86.5196 \\
USP & -0.5436 & 122.3 & 0.959 & 0.9563 & 1.179 & 28.5285 \\
\hline
\end{tabular}

tsunami in recorded history (Lay et al. 2005). After that, regional stress is redistributed, crustal deformation is continuous and many earthquakes occur to response it. After this giant earthquake, seismic stations are successively installed in the Sumatra area, the accuracy of earthquake monitoring is improved correspondingly. In this study, a two-year high quality BMKG continuous earthquake catalogue has been analyzed. The determined spatial and temporal diversities of seismic activity represented a complex plate interaction of this area. During this period, three earthquake sequences are well resolved and provided a good opportunity to evaluate the regional tectonics and potential hazards in near future.

\subsection{The Padang Earthquake Sequence}

The Padang earthquake sequence (named as G1 group in this study) is the first earthquake sequence occurred during the analyzed period. The earthquake distribution resolved by this study is in good agreement with the Padang earthquake study by McCloskey et al. (2010). Furthermore, the group seismicity has been analyzed to define the lineation of earthquakes and evaluate the related potential active faults. Along cross section A and beneath the southeastern offshore of Siberut island (Figs. 5 and 6), the lineation of earthquakes was shown as $\mathrm{f} 1, \mathrm{f} 2$, and $\mathrm{f} 3$ in Fig. 9a section $\mathrm{A}$ and considered as a series of splay faults. The $\mathrm{f} 2$ and $\mathrm{f} 3$, are within the same lineation faults that were studied by Wang et al. (2018), and it is shown overlap in Fig. 9a section $\mathrm{A}$, indicated by the blue and red colored circles, which correspond to the 2009 and 2005 earthquake clusters in their study, respectively. Hence, this study successfully recognized the $\mathrm{f} 1$, which is the lowest dipping of these three series of splay faults. These faults may confirm the concept of strain partitioning of plate boundary, which was first applied regionally to the Sunda Trench by Moore and Karig (1980). Thus, a series of splay faults connect to the Mentawai Fault and between the Mentawai and the Sumatra Fault zones subdivide the forearc sliver into several tectonic blocks, that being identified by seismic reflection and bathymetry studies by Berglar et al. (2017), which located at the northeastern offshore of Siberut island (between Si- berut and Batu Islands). The similar feature of splay fault has been reported by Waldhauser et al. (2012) beneath Aceh basin (northwestern offshore of Simeulue) through imaging aftershocks of the $2004 \mathrm{Mw} 9.2$ Sumatra-Andaman earthquake. Such a splay fault is usually represented by linking the similar thrust type event. The earthquake lineation obtained by this study may infer the position of a master splay fault that located above the plate interfaces (see the Fig. S2 of Supplementary Data). The same conclusion has been obtained by Konca et al. (2008) from the study of two 2007 earthquakes with $\mathrm{Mw} 8.4$ and 7.9 occurred in this region. They indicated also that the highest observed uplifted along the forearc located at eastern edge portion of the forearc Island or western edge of the Mentawai basin.

According the source depth $80 \mathrm{~km}$ of the Padang earthquake, the coseismic stress release of this event did not reach the Mentawai segment of the megathrust (McCloskey et al. 2010). Results of this study further indicated that the rupture of the shallow portion of this earthquake sequence came from the splay faults, which located above the megathrust, thus, it did not significantly release the accumulated stress on the megathrust. Our result indicated also that limited earthquake activity was identified at the Mentawai gap region (the portion between Batu and North Pagai islands) and considered as a locked asperity, as it is shown in Figs. 2a, 5, 6, and 7. Thus, it is a high potential candidate to generate destructive earthquake resulting tsunami in future. Hence, this region remains as a great threat of the Sumatra tsunamigenic earthquake. Results of this study implicated also that the Mentawai forearc sliver developed as a regional strike-slip fault, a plausible activity related to the reactivation of fracture zone within the subducting plate.

In this region, previous reflection studies coincidence with cross section Fig. 9a shows a southwest-dipping backthrust that intersect the seafloor at the western edge of the Mentawai basin (Singh et al. 2010; Mukti et al. 2012). Mukti et al. (2012) proposed that the backthrust lays on top of continental backstop that directly over ride the subducting plate and suggested that the activity of backthurst is waning and as a blind thrust. Although Singh et al. (2011) argued that the enhanced reflectivity of the backthrust may 
indicate it was active coseismically that observed by the scraps of past landslides observed at the eastern edge of the forearc. Examination from our result, there is no evidence of occurrence of shallow seismicity that may create such feature from the backthrust, and the uplifted of the forearc is possible generated by the splay fault (see the Fig. S2 of Supplementary Data). This finding is reinforced by the finding of the splay fault system by Berglar et al. (2017) at the northeastern offshore of Siberut and their extended conclusion that the Mentawai forearc sliver developed as a regional strike-slip duplex that divided by splay faults for each tectonic block.

\subsection{The Banyak Islands Earthquake Sequence}

The seismicity distribution of the Banyak Islands earthquake sequence (named as G2 group in this study) is confirm by the relocated earthquake from 2005 - 2006 at the same region by Tang et al. (2013) as well as the seismogenic zone study by Klingelhoefer et al. (2010). The 6 April 2010 Banyak main shock occurred within the source region of the 28 March 2005 Nias earthquake and it ruptured in the depth range $15-30 \mathrm{~km}$ (Lay et al. 2012). The southeast dipping of earthquake lineation at profile B of Fig. 9b may be possible cause of the activity of the USF (Lin et al. 2009). A series of such splay faults located beneath Aceh basin (northwestern offshore of Simeulue island) (Waldhauser et al. 2012) and at the western edge of the Mentawai basin were identified (Konca et al. 2008; Berglar et al. 2017). Those faults could be as source of tsunamigenic fault.

It should be noted that an earthquake with magnitude $M=7.2$ occurred on 9 May 2010 and located near the northern offshore of the Simeulue Island (Fig. 1). Although this event was reported by both the BMKG and ISC catalogues, however, limited aftershocks followed this event and this earthquake sequence cannot relocate using the HypoDD algorithm. Although, our resulted indicate a reasonable data coverage before and after HypoDD relocation within its temporal, magnitude and spatial (Figs. 4, 3b, and 5), which is shown that the major structure are not missing as well as some of the minor are successfully recognized. Therefore, we consider the 9 May $2010 \mathrm{M}=7.2$ event, which has a focal mechanism similar to the Banyak Islands earthquake should be considered as a large aftershock of the Banyak Islands earthquake sequence.

\subsection{The Mentawai Tsunami Earthquake Sequence}

The relocated spatial distribution of the 25 October $2010 \mathrm{Mw} 7.8$ Mentawai tsunami earthquake sequence named as G3 group in this study (Fig. 5) is shown in Figs. 8 and 9. Briggs et al. (2006) and Hsu et al. (2006) suggested that, in this area, the fault segment has released the major strain in the past great earthquakes. In our result, confirming this finding is that limited earthquakes were observed at the plate interface and its upper plate (Fig. 8). However, many events were found occurred beneath the trench within the subducting plate. Some of these events distributed vertically, which may indicate the discrepancy of the relocation process due to the insufficient station coverage are visible and it is cannot be neglected. However, based on previous studies, it may also have resulted from either faulting related to bending or unbending (Kawakatsu 1986; Collings et al. 2012) or reactivation of faults formed on the subducting plate prior to subduction (Savage 1969; Ranero et al. 2003; Collings et al. 2012). Lin et al. (2009) reported the characteristic of the FZ earthquakes, which distributed almost vertical with depth on range $10-50 \mathrm{~km}$. In this study, similar features have been observed in Fig. 9c, despite we do not have a good station coverage. It should indicate that the fault geometries of FZ1 and FZ2 obviously viewed along the cross-section $\mathrm{D}$, which oriented its strike perpendicular to the fracture zone of the subducted plate (Fig. 5). Based on our results, we agreed the conclusion of Lin et al. (2009), that, those earthquakes were induced by the reactivation of the subducting plate fracture zone. Implications of this fracture zone indicated a possibility of that, those fracture zones can be a fossil earthquake rupture zones similar to recent occurred two great earthquakes within the oceanic plate and strike-slip faulting (Meng et al. 2012; Yue et al. 2012).

Along the cross-section $\mathrm{C}$, some shallow events relocated in this study are far from the trench (Fig. 9c). The similar pattern was found by Collings et al. (2012) and considered as a backthrust fault. However, after the detail examination, we do not have strong confidence to suggest the similar conclusion although some of the focal mechanism may indicate such structure exist, as it is shown in Fig. 9c section C. Following our relocation, those events were not horizontally (map view) concentrated.

\subsection{The Other Earthquake Activities}

Although only limited earthquakes along the SFZ were observed during this two years period (Fig. 5). However, the seismicity along SFZ has its magnitude between 6 and 7.7 (Sieh and Natawidjaja 2000). Thus, the SFZ is capable to produce a large magnitude of earthquakes. The SFZ is a fault with right lateral strike slip movement associated with a series of valleys along the mountain chain (Sieh and Natawidjaja 2000). Its movement may relate to the strain partition of oblique collision of the Australian oceanic plate subducting beneath the Sunda continental plate. Beside the seismic activity following large earthquakes occurred during this period, there are several earthquakes with depth near $150 \mathrm{~km}$ occurred beneath northern Sumatra and the same as ISC reported background seismicity (Fig. 5). To trace the spatial distribution of those earthquakes, it may 
infer the activation of slab tear from the subducted fracture zone, which were previously reported by Fauzi et al. (1996) and Koulakov et al. (2016).

\section{CONCLUSION}

A two year BMKG earthquake travel time data have been reprocessed based on the hypocenter double difference technique. The new analysis reveals the high-precision seismic activity of three earthquake sequences along the Sumatra subduction zone. Following, a statistical analysis of polynomial linear fitting has been proposed to identify lineation of those relocated earthquake sequences. Results of this study indicated that:

(1) The rupture of the shallow portion of the Padang earthquake sequence came from the splay faults which located above the megathrust and it did not significantly release the accumulated stress in the plate interface. Hence, the Mentawai gap of the Sumatra megathrust is remains as a great threat of tsunamigenic earthquake.

(2) A northwest-southeast seismicity lineation is identified following the Banyak Islands earthquake sequence and considered as possibly induced by seismic activities along the upper splay fault.

(3) Within the 2010 Mentawai tsunami earthquake sequence aftershock zone, some near vertical with a slight dipping to the northwest-southeast seismicity lineations were identified on the subducting oceanic plate. We recognized those earthquakes were induced by the reactivation of the subducting plate fracture zone.

(4) Some deep events beneath the Toba volcano, northern Sumatra were identified and considered as the possible activation of slab tear from the subducted fracture zone.

Acknowledgements We thank Prof. Jean Claude Sibuet and Prof. Yi-Ling Huang from Institute of Geosciences, NTOU and Prof. Jing-Yi Lin from Department of Earth Science, NCU for their valuable discussion and suggestion about the manuscript. Thank also due to Prof. Shengji Wei from Earth Observatory Singapore, for its valuable suggestion along with his short visit to Institute of Earth Science, Academia Sinica. We particularly thank Dr. Chun-Han Chan from Nanyang Technological University, Singapore, an anonymous reviewer and the Editor Prof. Ruey-Juin Rau for their careful and very useful reviews and for the opportunity to improve the manuscript accordingly. The GMT software package was used to draw the figures (Wessel and Smith 1991). This study was funded by the Ministry of Science and Technology, Taiwan, grant MOST 105-2923-M006-006-MY3 and grant MOST 107-2119-M-001-048.

\section{REFERENCES}

Araki, E., M. Shinohara, K. Obana, T. Yamada, Y. Kaneda,
T. Kanazawa, and K. Suyehiro, 2006: Aftershock distribution of the 26 December 2004 Sumatra-Andaman earthquake from ocean bottom seismographic observation. Earth Planets Space, 58, 113-119, doi: 10.1186/ BF03353367. [Link]

Barber, A. J., M. J. Crow, and J. S. Milsom, 2005: Sumatra: Geology, Resources and tectonic Evolutionm, Geological Society, London, Memoirs, Vol. 31, The Geological Society, London, UK, 290 pp, doi: 10.1144/GSL. MEM.2005.031.01.19. [Link]

Barckhausen, U., 2006: The segmentation of the subduction zone offshore Sumatra: Relations between upper and lower plate. AGU Fall Meeting Abstracts U53A-0029.

Berglar, K., C. Gaedicke, S. Ladage, and H. Thöle, 2017: The Mentawai forearc sliver off Sumatra: A model for a strike-slip duplex at a regional scale. Tectonophysics, 710-711, 225-231, doi: 10.1016/j.tecto.2016.09.014. [Link]

Bilek, S. L., E. R. Engdahl, H. R. DeShon, and M. El Hariri, 2011: The 25 October 2010 Sumatra tsunami earthquake: Slip in a slow patch. Geophys. Res. Lett., 38, doi: 10.1029/2011GL047864. [Link]

Briggs, R. W., K. Sieh, A. J. Meltzner, D. Natawidjaja, J. Galetzka, B. Suwargadi, Y. Hsu, M. Simons, N. Hananto, I. Suprihanto, D. Prayudi, J.-P. Avouac, L. Prawirodirdjo, and Y. Bock, 2006: Deformation and Slip Along the Sunda Megathrust in the Great 2005 Nias-Simeulue Earthquake. Science, 311, 1897-1901, doi: 10.1126/science.1122602. [Link]

Chlieh, M., J. P. Avouac, K. Sieh, D. H. Natawidjaja, and J. Galetzka, 2008: Heterogeneous coupling of the Sumatran megathrust constrained by geodetic and paleogeodetic measurements. J. Geophys. Res., 113, doi: 10.1029/2007JB004981. [Link]

Collings, R., D. Lange, A. Rietbrock, F. Tilmann, D. Natawidjaja, B. Suwargadi, M. Miller, and J. Saul, 2012: Structure and seismogenic properties of the Mentawai segment of the Sumatra subduction zone revealed by local earthquake traveltime tomography. J. Geophys. Res., 117, doi: 10.1029/2011JB008469. [Link]

Delescluse, M. and N. Chamot-Rooke, 2007: Instantaneous deformation and kinematics of the India-Australia Plate. Geophys. J. Int., 168, 818-842, doi: 10.1111/j.1365246X.2006.03181.x. [Link]

Deplus, C., M. Diament, H. Hébert, G. Bertrand, S. Dominguez, J. Dubois, J. Malod, P. Patriat, B. Pontoise, and J.-J. Sibilla, 1998: Direct evidence of active deformation in the eastern Indian oceanic plate. Geology, 26, 131-134, doi: 10.1130/0091-7613(1998)026< 0131:DEOADI>2.3.CO;2. [Link]

Engdahl, E. R., A. Villasenor, H. R. DeShon, and C. H. Thurber, 2007: Teleseismic relocation and assessment of seismicity (1918-2005) in the region of the 2004 Mw 9.0 Sumatra-Andaman and 2005 Mw 8.6 Nias 
Island great earthquakes. Bull. Seismol. Soc. Am., 97, S43-S61, doi: 10.1785/0120050614. [Link]

Fauzi, R. McCaffrey, D. Wark, Sunaryo, and P. Y. Prih Haryadi, 1996: Lateral variation in slab orientation beneath Toba Caldera, northern Sumatra. Geophys. Res. Lett., 23, 443-446, doi: 10.1029/96GL00381. [Link]

Hayes, G. P., D. J. Wald, and R. L. Johnson, 2012: Slab1.0: A three-dimensional model of global subduction zone geometries. J. Geophys. Res., 117, B01302, doi: 10.1029/2011JB008524. [Link]

Hsu, Y.-J., M. Simons, J.-P. Avouac, J. Galetzka, K. Sieh, M. Chlieh, D. Natawidjaja, L. Prawirodirdjo, and Y. Bock, 2006: Frictional Afterslip Following the 2005 Nias-Simeulue Earthquake, Sumatra. Science, 312, 1921-1926, doi: 10.1126/science.1126960. [Link]

Huang, B.-S., Y.-L. Huang, P.-L. Leu, and S.-J. Lee, 2011: Estimation of the rupture velocity and fault length of the 2004 Sumatra-Andaman earthquake using a dense broadband seismic array in Taiwan. J. Asian Earth Sci., 40, 762-769, doi: 10.1016/j.jseaes.2010.10.020. [Link]

Ishii, M., P. M. Shearer, H. Houston, and J. E. Vidale, 2007: Teleseismic P wave imaging of the 26 December 2004 Sumatra-Andaman and 28 March 2005 Sumatra earthquake ruptures using the Hi-net array. J. Geophys. Res., 112, B11307, doi: 10.1029/2006JB004700. [Link]

Kawakatsu, H., 1986: Downdip tensional earthquakes beneath the Tonga arc: A double seismic zone? J.Geophys. Res., 91, 6432-6440, doi: 10.1029/JB091iB06p06432. [Link]

Kennett, B. L. N., E. R. Engdahl, and R. Buland, 1995: Constraints on seismic velocities in the Earth from traveltimes. Geophys. J. Int., 122, 108-124, doi: 10.1111/j.1365-246X.1995.tb03540.x. [Link]

Kissling, E., W. L. Ellsworth, D. Eberhart-Phillips, and U. Kradolfer, 1994: Initial reference models in local earthquake tomography. J. Geophys. Res., 99, 1963519646, doi: 10.1029/93JB03138. [Link]

Klingelhoefer, F., M. A. Gutscher, S. Ladage, J. X. Dessa, D. Graindorge, D. Franke, C. André, H. Permana, T. Yudistira, and A. Chauhan, 2010: Limits of the seismogenic zone in the epicentral region of the 26 December 2004 great Sumatra-Andaman earthquake: Results from seismic refraction and wide-angle reflection surveys and thermal modeling. J. Geophys. Res., 115, B01304, doi: 10.1029/2009JB006569. [Link]

Konca, A. O., V. Hjorleifsdottir, T.-R. A. Song, J.-P. Avouac, D. V. Helmberger, C. Ji, K. Sieh, R. Briggs, and A. Meltzner, 2007: Rupture kinematics of the $2005 \mathrm{Mw}$ 8.6 Nias-Simeulue earthquake from the joint inversion of seismic and geodetic data. Bull. Seismol. Soc. Am., 97, S307-S322, doi: 10.1785/0120050632. [Link]

Konca, A. O., J. P. Avouac, A. Sladen, A. J. Meltzner, K. Sieh, P. Fang, Z. Li, J. Galetzka, J. Genrich, M. Chlieh, D. H. Natawidjaja, Y. Bock, E. J. Fielding, C. Ji, and
D. V. Helmberger, 2008: Partial rupture of a locked patch of the Sumatra megathrust during the 2007 earthquake sequence. Nature, 456, 631-635, doi: 10.1038/ nature 07572. [Link]

Koulakov, I., E. Kasatkina, N. M. Shapiro, C. Jaupart, A. Vasilevsky, S. El Khrepy, N. Al-Arifi, and S. Smirnov, 2016: The feeder system of the Toba supervolcano from the slab to the shallow reservoir. Nat. Comm., 7, doi: 10.1038/ncomms12228. [Link]

Lange, D., F. Tilmann, A. Rietbrock, R. Collings, D. H. Natawidjaja, B. W. Suwargadi, P. Barton, T. Henstock, and T. Ryberg, 2010: The Fine Structure of the Subducted Investigator Fracture Zone in Western Sumatra as Seen by Local Seismicity. Earth Planet. Sci. Lett., 298, 47-56, doi: 10.1016/j.eps1.2010.07.020. [Link]

Lay, T., H. Kanamori, C. J. Ammon, M. Nettles, S. N. Ward, R. C. Aster, S. L. Beck, S. L. Bilek, M. R. Brudzinski, R. Butler, H. R. DeShon, G. Ekström, K. Satake, and S. Sipkin, 2005: The Great Sumatra-Andaman Earthquake of 26 December 2004. Science, 308, 1127-1133, doi: 10.1126/science.1112250. [Link]

Lay, T., C. J. Ammon, H. Kanamori, Y. Yamazaki, K. F. Cheung, and A. R. Hutko, 2011: The 25 October 2010 Mentawai tsunami earthquake $\left(\mathrm{M}_{\mathrm{w}} 7.8\right)$ and the tsunami hazard presented by shallow megathrust ruptures. Geophys. Res. Lett., 38, doi: 10.1029/2010GL046552. [Link]

Lay, T., H. Kanamori, C. J. Ammon, K. D. Koper, A. R. Hutko, L. Ye, H. Yue, and T. M. Rushing 2012: Depth-varying rupture properties of subduction zone megathrust faults. J. Geophys. Res., 117, B04311, doi: 10.1029/2011JB009133. [Link]

Lin, J. Y., X. Le Pichon, C. Rangin, J. C. Sibuet, and T. Maury, 2009: Spatial aftershock distribution of the 26 December 2004 great Sumatra-Andaman earthquake in the northern Sumatra area. Geochem. Geophys. Geosyst., 10, doi: 10.1029/2009GC002454. [Link]

Mathworks, 2017: Curve Fitting Toolbox: For Use with MATLAB®: User's Guide, MathWorks, Natick, MA.

McCloskey, J., D. Lange, F. Tilmann, S. S. Nalbant, A. F. Bell, D. H. Natawidjaja, and A. Rietbrock, 2010: The September 2009 Padang earthquake. Nat. Geosci., 3, 70-71, doi: 10.1038/ngeo753. [Link]

Meltzner, A. J., K. Sieh, M. Abrams, D. C. Agnew, K. W. Hudnut, J. P. Avouac, and D. H. Natawidjaja, 2006: Uplift and subsidence associated with the great AcehAndaman earthquake of 2004. J. Geophys. Res., 111, doi: 10.1029/2005JB003891. [Link]

Meng, L., J.-P. Ampuero, J. Stock, Z. Duputel, Y. Luo, and V.C. Tsai, 2012: Earthquake in a maze: Compressional rupture branching during the $2012 \mathrm{Mw} 8.6$ Sumatra earthquake. Science, 337, 724-726, doi: 10.1126/science.1224030. [Link]

Moore, G. F. and D. E. Karig, 1980: Structural geology of 
Nias Island, Indonesia: Implications for subduction zone tectonics. Am. J.Sci., 280, 193-223, doi: 10.2475/ ajs.280.3.193. [Link]

Mukti, M. M., S. C. Singh, I. Deighton, N. D. Hananto, R. Moeremans, and H. Permana, 2012: Structural evolution of backthrusting in the Mentawai Fault Zone, offshore Sumatran forearc. Geochem. Geophys. Geosyst., 13, doi: 10.1029/2012GC004199. [Link]

Natawidjaja, D. H., K. Sieh, S. N. Ward, H. Cheng, R. L. Edwards, J. Galetzka, and B. W. Suwargadi, 2004: Paleogeodetic records of seismic and aseismic subduction from central Sumatran microatolls, Indonesia. J. Geophys. Res., 109, B04306, doi: 10.1029/2003JB002398. [Link]

Natawidjaja, D. H., K. Sieh, M. Chlieh, J. Galetzka, B. W. Suwargadi, H. Cheng, R. L. Edwards, J. P. Avouac, and S. N. Ward, 2006: Source parameters of the great Sumatran megathrust earthquakes of 1797 and 1833 inferred from coral microatolls. J. Geophys. Res., 111, doi: 10.1029/2005JB004025. [Link]

Newcomb, K. R. and W. R. McCann, 1987: Seismic history and seismotectonics of the Sunda Arc. J. Geophys. Res., 92, 421-439, doi: 10.1029/JB092iB01p00421. [Link]

Prawirodirdjo, L., R. McCaffrey, C. D. Chadwell, Y. Bock, and C. Subarya, 2010: Geodetic observations of an earthquake cycle at the Sumatra subduction zone: Role of interseismic strain segmentation. J. Geophys. Res., 115, B03414, doi: 10.1029/2008JB006139. [Link]

Ranero, C. R., J. Phipps Morgan, K. McIntosh, and C. Reichert, 2003: Bending-related faulting and mantle serpentinization at the Middle America trench. Nature, 425, 367-373, doi: 10.1038/nature01961. [Link]

Rietbrock, A. and F. Waldhauser, 2004: A narrowly spaced double-seismic zone in the subducting Nazca plate. Geophys. Res. Lett., 31, L10608, doi: 10.1029/2004GL019610. [Link]

Savage, J. C., 1969: The mechanics of deep-focus faulting. Tectonophysics, 8, 115-127, doi: 10.1016/00401951(69)90085-7. [Link]

Shih, M. H., B. S. Huang, L. Zhu, H. Y. Yen, T. M. Chang, W. G. Huang, and C. Y. Wang, 2014: Fault orientation determination for the 4 March 2008 Taoyuan earthquake from dense near-source seismic observations. Terr. Atmos. Ocean. Sci., 25, 637-645, doi: 10.3319/ TAO.2014.05.19.01(T). [Link]

Sibuet, J., C. Rangin, X. Lepichon, S. Singh, A. Cattaneo, D. Graindorge, F. Klingelhoefer, J. Lin, J. Malod, and T. Maury, 2007: 26th December 2004 great SumatraAndaman earthquake: Co-seismic and post-seismic motions in northern Sumatra. Earth Planet. Sci. Lett., 263, 88-103, doi: 10.1016/j.epsl.2007.09.005. [Link]

Sieh, K. and D. Natawidjaja, 2000: Neotectonics of the Sumatran fault, Indonesia. J. Geophys. Res., 105, 28295-
28326, doi: 10.1029/2000JB900120. [Link]

Singh, S. C., N. D. Hananto, A. P. S. Chauhan, H. Permana, M. Denolle, A. Hendriyana, and D. Natawidjaja, 2010: Evidence of active backthrusting at the NE Margin of Mentawai Islands, SW Sumatra. Geophys. J. Int., 180, 703-714, doi: 10.1111/j.1365-246X.2009.04458.x. [Link]

Singh, S. C., N. D. Hananto, and A. P. S. Chauhan, 2011: Enhanced reflectivity of backthrusts in the recent great Sumatran earthquake rupture zones. Geophys. Res. Lett., 38, doi: 10.1029/2010GL046227. [Link]

Tang, G., P. J. Barton, L. C. McNeill, T. J. Henstock, F. Tilmann, S. M. Dean, M. D. Jusuf, Y. S. Djajadihardja, H. Permana, F. Klingelhoefer, and H. Kopp, 2013: 3-D active source tomography around Simeulue Island offshore Sumatra: Thick crustal zone responsible for earthquake segment boundary. Geophys. Res. Lett., 40, 48-53, doi: 10.1029/2012GL054148. [Link]

Tsang, L. L. H., A. J. Meltzner, B. Philibosian, E. M. Hill, J. T. Freymueller, and K. Sieh, 2015: A 15 year slow-slip event on the Sunda megathrust offshore Sumatra. Geophys. Res. Lett., 42, 6630-6638, doi: 10.1002/2015GL064928. [Link]

Waldhauser, F., 2001: hypoDD -- A Program to Compute Double-Difference Hypocenter Locations. USGS Numbered Series, Open-File Report 2001-113, 25 pp, doi: 10.3133/ofr01113. [Link]

Waldhauser, F. and W. L. Ellsworth, 2000: A DoubleDifference Earthquake Location Algorithm: Method and Application to the Northern Hayward Fault, California. Bull. Seismol. Soc. Am., 90, 1353-1368, doi: 10.1785/0120000006. [Link]

Waldhauser, F., D. P. Schaff, T. Diehl, and E. R. Engdahl, 2012: Splay faults imaged by fluid-driven aftershocks of the $2004 \mathrm{Mw} 9.2$ Sumatra-Andaman earthquake. Geology, 40, 243-246, doi: 10.1130/G32420.1. [Link]

Wang, X., K. E. Bradley, S. Wei, and W. Wu, 2018: Active backstop faults in the Mentawai region of Sumatra, Indonesia, revealed by teleseismic broadband waveform modeling. Earth Planet. Sci. Lett., 483, 29-38, doi: 10.1016/j.epsl.2017.11.049. [Link]

Wessel, P. and W. H. F. Smith, 1991: Free software helps map and display data. Eos, Trans., AGU, 72, 441-448, doi: 10.1029/90EO00319. [Link]

Wiseman, K., P. Banerjee, R. Bürgmann, K. Sieh, D. S. Dreger, and I. Hermawan, 2012: Source model of the $2009 \mathrm{Mw}$ 7.6 Padang intraslab earthquake and its effect on the Sunda megathrust. Geophys. J. Int., 190, 17101722, doi: 10.1111/j.1365-246X.2012.05600.x. [Link]

Yue, H., T. Lay, and K. D. Koper, 2012: En échelon and orthogonal fault ruptures of the 11 April 2012 great intraplate earthquakes. Nature, 490, 245-249, doi: 10.1038/ nature11492. [Link] 